\title{
Production and role of epicormic shoots in pruned hybrid poplar: effects of clone, pruning season and intensity
}

\author{
Annie Desrochers • Vincent Maurin • Emilie Tarroux
}

Received: 31 July 2014 / Accepted: 28 November 2014 / Published online: 19 December 2014

(C) INRA and Springer-Verlag France 2014

\begin{abstract}
- Key message Pruning one third of crown length in summer produced the least number of epicormic branches after two growing seasons. Epicormic branches can be removed without compromising tree growth.

- Context The formation of epicormic shoots is often observed following pruning treatments, but their role in the overall tree growth is unknown.

- Aims The objectives of this study were to examine how pruning intensity and season affect the production of epicormic branches and how their presence (or removal) affects tree growth and total non-structural carbohydrate reserves in the roots.

- Methods Trees from four hybrid poplar clones were pruned in fall, spring, and summer at two intensities $1 / 3$ and $2 / 3$ of the crown length and an unpruned control. Produced epicormic branches were removed from half the trees.

- Results Pruning intensity and season were the most important factors affecting the number and biomass of epicormic shoots while clone was not. Pruning 1/3 crown length in summer reduced the emergence of epicormic shoots compared
\end{abstract}

\section{Handling Editor: Erwin Dreyer}

Contribution of the co-authors Maurin realized the field and laboratory work, ran some of the data analysis, and wrote the initial manuscript. Desrochers designed the experiment, supervised the work, coordinated the research project, and edited the manuscript. Tarroux ran the data analysis, produced graphs, and wrote parts of the manuscript.

A. Desrochers $(\bowtie) \cdot V$. Maurin $\cdot$ E. Tarroux

Forest Research Institute, Université du Québec en

Abitibi-Témiscamingue, 341 rue Principale Nord, Amos,

Québec J9T 2L8, Canada

e-mail: annie.desrochers@uqat.ca

V. Maurin

e-mail: Vincent.maurin@uqat.ca

E. Tarroux

e-mail: emilie.tarroux@uqat.ca to $2 / 3$ and spring or fall pruning. Two years after pruning, the removal of epicormic shoots did not affect height or diameter at breast height of trees, and their presence did not restore root total non-structural carbohydrates reserves to unpruned levels. - Conclusion We concluded that pruning should be done in summer at $1 / 3$ of the crown length to reduce epicormic shoot formation and to avoid decreases in stem growth. If epicormic shoots appear, they can be removed without compromising tree growth.

Keywords Populus $\cdot$ Tree physiology $\cdot$ Silviculture $\cdot$ Branch

\section{Introduction}

Pruning treatments are used to add value to crop trees in managed stands by increasing the amount of clear, knot-free wood (Hubert and Courraud 1994; Waring and O'Hara 2005). However, pruning might also promote the production of epicormic shoots, branches that form along the trunk of trees after they have been pruned (Auchmoody 1972). Epicormic branching is common in intensively managed hybrid poplar plantations (Shock et al. 2003; Smith and Blom 1966; Tabbush and Beaton 1998), most often following pruning treatments (DeBell et al. 2002; Hubert and Courraud 1994; Isebrands et al. 2007; van Oosten 2006). These epicormic branches arise from buds found on or under the bark that are often called "dormant buds" (Kozlowski and Pallardy 1997) and can be of proventitious or adventitious origin (Fink 1983; Meier et al. 2012; Stone and Stone 1943). Proventitious buds develop from existing buds and are located at the axil of leaves (Stone and Stone 1943) and can burst when the sequential branch to which they are attached is removed or dying (Meier et al. 2012), whereas adventitious buds arise outside the normal phyllotaxy and may be produced on the callus located on the cambium layer after wounding of surrounding tissues 
(Fink 1983; Meier et al. 2012). Epicormic shoots are thus an impediment to the success of pruning operations to produce high-quality timber, because their apparition produce additional knots that reduce timber quality and value (Fontaine et al. 1999; Remphrey and Davidson 1992). Plantation managers thus need to know (i) how trees will react to pruning in terms of epicormic shoot production, and how the latter will affect trunk growth and quality, and (ii) if it is useful to remove these epicormic shoots once they have sprouted in terms of growth and quality of stems but also in terms of an eventual re-sprouting of undesirable branches.

Epicormic shoot formation is generally thought to be a response to a sudden light increase (Gordon et al. 2006; Wignall and Browning 1988) or stress (Stone and Stone 1943). Epicormic branching can also be considered as a mechanism for re-establishment or maintenance of a functional crown (Deal et al. 2003), in response to a physiological imbalance between photosynthetic and nonphotosynthetic organs (Nicolini et al. 2001). However, significant knowledge gaps remain, especially for the role of these branches in overall tree physiology: Does their production after pruning lead to increased (energy source) or decreased (energy sink) diameters of the main stem? A source is an organ which supplies carbon (net exporter), while a sink is an organ which uses carbon (net importer) (Kozlowski 1992). Since epicormic shoots are usually produced rapidly after pruning and can have very fast growth rates and large biomasses, they might initially be very strong sinks and cause growth reductions or stagnation of the main stem. On the other hand, since they rapidly produce new leaf area on heavily pruned stems (Deal et al. 2003; Takiya et al. 2010), they might rapidly compensate the loss of photosynthetic area of pruned crowns and become an important energy source for the tree (Nicolini et al. 2001). Since the imbalance between photosynthetic vs non-photosynthetic tissues created by pruning increases with pruning intensity, it seems logical that the occurrence of epicormic branches would increase with pruning intensity (O'Hara and Valappil 2000). However, this response could diverge according to the season when pruning is done, since season may also affect epicormic shoot formation (Bachelard 1969), most likely due to the hormonal and annual carbon allocation that can regulate epicormic branching (Meier et al. 2012).

The objectives of this study were to examine how pruning intensity and season affect the production of epicormic branches in hybrid poplar clones of different parentages and how their presence (or removal) affects tree growth and total non-structural carbohydrate reserves in the roots. We pruned four hybrid poplar clones at three pruning intensities (unpruned, $1 / 3$ and $2 / 3$ of crown length) and three seasons (fall, spring, and summer). We hypothesized that severe pruning ( $2 / 3$ crown length) done during the growing season (summer) would result in more epicormic branches produced, due to a greater sudden light increase of the stems. Because epicormic branches usually get very large rapidly (energy sink) while located low on the stem (low light conditions), we hypothesized that their production would negatively affect stem growth and that their subsequent removal would lower root total non-structural carbohydrate reserves. The decision to remove epicormic branches after pruning brings supplementary costs to foresters wanting to produce knot-free timber and requires more data to make sensible silvicultural choices.

\section{Material and methods}

\subsection{Study site}

The studied plantation was established in 2007 at the New Liskeard Agricultural Research Station of Guelph University in North-Eastern Ontario (47 $31^{\prime} 15^{\prime \prime} \mathrm{N}, 79^{\circ} 39^{\prime} 52^{\prime \prime}$ $\mathrm{W})$. The regional surficial geology is characterized by lacustrine clays and sands from the post-glacial Lake Barlow (Rowe 1972), and the soil type was a Humic Gleysol (Canada Soil Survey Committee 1987). Between 1981 and 2010, annual precipitations for the region averaged $837 \mathrm{~mm}$ (rainfall $655 \mathrm{~mm}$, snowfall $181 \mathrm{~cm}$ ) with an average daily temperature of $3.1{ }^{\circ} \mathrm{C}$ and 2,641 degreedays above $0{ }^{\circ} \mathrm{C}$ (Environment Canada 2014; Ville Marie weather station, about $25 \mathrm{~km} \mathrm{NW}$ of the study area).

The site was plowed in October 2006 and crosscultivated with disks followed by a pre-emergent herbicide application in spring 2007 before planting trees at a $3.5-\mathrm{m} \times$ $3.5-\mathrm{m}$ spacing (816 stems $\mathrm{ha}^{-1}$ ). The planting stock consisted of dormant 1-year-old bareroot trees. Planting was followed by fertilization with 18-23-18 (N-P-K, $\left.110 \mathrm{~g} \mathrm{tree}^{-1}\right)$. Annual weed control consisted of crosscultivation with disks followed by herbicide application (RoundupTM). Four hybrid poplar clones were chosen based on their different parentage: 1079 (Populus $\times$ jackii (Populus balsamifera $\times$ Populus deltoides)), 747210 (Populus balsamifera $\times \underline{\text { Populus }}$ trichocarpa), 915319 (Populus maximowiczii $\times$ Populus balsamifera), and DN2 (Populus deltoides $\times$ Populus nigra).

Trees were planted in a split-split plot randomized complete block design with three blocks (replicates), each containing four plots of 100 trees (10 rows $\times 10$ trees), one for each clone. Each plot was randomly divided into three pruning seasons (October $2009=$ fall, March $2010=$ spring, or June $2010=$ summer) and three intensities (unpruned, $1 / 3$ or $2 / 3$ of the crown length; Smith et al. 1997). One row of trees was used for each treatment combination. To compare trees with and without 
epicormic shoots, each row was divided in two sections; epicormic shoots that sprouted after pruning were periodically removed from the first five trees, while they were left to grow on the other five trees. For the study, we considered unpruned trees as trees without epicormic shoots.

\subsection{Field sampling}

Height and diameter at breast height (dbh) of all the trees were measured at the end of each growing season from 2009 to 2011 (see Table 1 from Maurin and DesRochers 2013).

At the end of August 2010, root samples were collected for determination of total non-structural carbohydrates (TNC) by cutting a disk from one of the main roots. To compare TNC concentrations between trees with or without epicormic shoots, we randomly selected one tree per row to collect a root sample per pruning treatment in pruned trees with and without epicormic shoots and unpruned trees from each of the four clones $(n=180$, since unpruned trees were considered as having no epicormic branches).

In September 2010, we selected one tree with epicormic shoots per pruning treatment for each clone $(n=72)$. For those selected trees, all epicormic shoots (with leaves) formed in 2010 (2010) between the ground level and pruning height were collected. The same operation was repeated in September 2011 on the same trees, to collect newly formed epicormic shoots (2011 new) if any $(n=72)$. At the same date, we also selected 72 other trees to collect 2-year-old epicormic shoots (2011_old). We measured branch biomass, length, and basal diameter as well as leaf biomass on each sample. Since some biomass data went missing in the lab, we calculated branch volume from its basal diameter and length values and used a linear regression between branch biomass and volume $\left(R^{2}=0.985\right)$ to estimate branch biomass on missing samples. Branch volume was calculated from the following equation:

$V=1 / 3\left(H \times \pi \times D^{2}\right) / 4$

where $V$ is the branch volume in cubic centimeter, $D$ the basal diameter of the branch in centimeter, and $H$ the branch length in centimeter then converted to biomass.

\subsection{Laboratory work}

Shoots were brought to the lab in large plastic bags and stored in a refrigerator at $2{ }^{\circ} \mathrm{C}$ before they were oven-dried at $65{ }^{\circ} \mathrm{C}$ until constant mass was obtained. Branch biomass consisted of dry mass of shoots and leaves.

Root samples for carbohydrate analysis were ovendried at $65{ }^{\circ} \mathrm{C}$ until constant mass was obtained and ground to pass a 40-mesh screen of a Wiley mill (model 3383-L10; Thomas Scientific, Swedesboro, NJ). Soluble sugars were extracted by boiling three times in $80 \%$ ethanol at $95{ }^{\circ} \mathrm{C}$. Phenol-sulfuric acid was used to analyze the ethanol extract for total sugar concentration. Starch was digested using an enzyme mixture of $\alpha$ amylase and amyloglucosidase followed by the colorimetric measurement of the glucose hydrolysate using a peroxidase-glucose oxidase-o-dianisidine reagent (Chow and Landhäusser 2004).

\subsection{Statistical analyses}

Statistical analyses were done with $\mathrm{R}$ software version 2.15.1 (R Development Core Team 2012). Linear mixed effects models were used to model treatment effects on each response variable. To reflect the plantation design, all models included random effects that consisted of block and clone nested in block. We used multiple comparisons of means (Tukey's tests) to find differences among treatments with the multcomp package (Hothorn et al. 2008). The fit of the global model was assessed for each analysis. The global model was composed of all the factors tested and their interactions.

The effect of pruning intensity $(1 / 3,2 / 3)$, clone (2079, 747210, 915319, and DN2), season (fall, spring, and summer), and treatment (with or without epicormic branches) on the number and biomass of epicormic shoots produced by trees was analyzed using the lme function from the nlme package (Pinheiro et al. 2012). A $\log$ transformation was applied to normalize residuals and improve homoscedasticity, but results and predicted values are presented in back-transformed units. We used stepwise and backward model selection to determine the most suitable model for the number of epicormic shoots.

To analyze the effects of epicormic shoots on tree height and dbh growth in 2010 and 2011, we built four models (DBH10, HEIGHT10, DBH11, and HEIGHT11) using the lme function from the nlme package (Pinheiro et al. 2012). We included initial tree size measurements (fall 2009) as covariates. As all the trees (with and without epicormic shoots) were used for this analysis, parameter "treatment" in the models corresponds to the pruning intensity associated with the presence $(1 / 3$ epi or $2 / 3$ epi) or absence $(1 / 3$ or $2 / 3)$ of epicormic shoots, also including the unpruned trees. Parameter tree was added as a random effect for this analysis. 
Table 1 Global models testing the number (NUMB) and biomass (MASS) of epicormic shoots produced according to pruning intensity (1/3 and 2/3 pruning of crown length), clone (1079, 747210, 915319, and DN2), season (fall, spring, and summer), and year (2010, 2011_new, and 2011_old)

\begin{tabular}{|c|c|c|c|c|c|c|c|c|}
\hline \multirow[t]{2}{*}{ Tested factors } & \multicolumn{2}{|l|}{ numDF } & \multicolumn{2}{|l|}{ denDF } & \multicolumn{2}{|l|}{$F$ value } & \multicolumn{2}{|l|}{$P$ value } \\
\hline & NUMB & MASS & NUMB & MASS & NUMB & MASS & NUMB & MASS \\
\hline Intensity & 1 & 1 & 135 & 112 & 20.08 & 16.84 & $<0.001$ & $<0.001$ \\
\hline Season & 2 & 2 & 135 & 112 & 11.61 & 13.24 & $<0.001$ & $<0.001$ \\
\hline Clone & 3 & 3 & 6 & 6 & 3.39 & 1.47 & 0.10 & 0.31 \\
\hline Year & 2 & 2 & 135 & 24 & 3.81 & 67.47 & 0.02 & $<0.001$ \\
\hline Clone:Year & 6 & 6 & 135 & 24 & 1.65 & 1.10 & 0.14 & 0.39 \\
\hline Intensity:Year & 2 & 2 & 135 & 24 & 0.46 & 0.86 & 0.63 & 0.44 \\
\hline Intensity:Clone & 3 & 3 & 135 & 112 & 0.72 & 0.71 & 0.54 & 0.55 \\
\hline Season:Year & 4 & 4 & 135 & 24 & 2.63 & 5.85 & 0.04 & $<0.001$ \\
\hline Season:Clone & 6 & 6 & 135 & 112 & 2.27 & 1.58 & 0.04 & 0.16 \\
\hline Intensity:Season & 2 & 2 & 135 & 112 & 2.27 & 2.39 & 0.11 & 0.10 \\
\hline Intensity:Clone:Year & 6 & 6 & 135 & 24 & 0.66 & 0.93 & 0.68 & 0.49 \\
\hline Season:Clone:Year & 12 & 12 & 135 & 24 & 0.86 & 0.82 & 0.59 & 0.63 \\
\hline Intensity:Season:Year & 4 & 4 & 135 & 24 & 0.37 & 1.92 & 0.83 & 0.14 \\
\hline Intensity:Season:Clone & 6 & 6 & 135 & 112 & 0.11 & 0.82 & 0.99 & 0.56 \\
\hline Intensity:Clone:Year:Season & 12 & 12 & 135 & 24 & 0.97 & 0.90 & 0.48 & 0.56 \\
\hline
\end{tabular}

Statistically significant values $(P<0.05)$ are given in bold. The factor year 2010 corresponds to epicormic branches produced in 2010, 2011_new corresponds to epicormic branches produced in 2011, and 2011_old corresponds to epicormic branches produced in 2010 and 2011 and collected at the end of 2011 growing season. NumDF and denDF are the numerator and denominator of degrees of freedom, respectively

The effect of pruning (unpruned, 1/3 pruning with or without epicormic shoots and 2/3 with or without epicormic shoots), clone, and season on total non-structural carbohydrates was also tested using lme function (Pinheiro et al. 2012). We used stepwise and backward model selection to determine the most suitable model.
Table 2 Selected model testing the effects of pruning intensity (1/3 and $2 / 3$ crown length), clone $(1079,747210,915319$, and DN2), season (fall, spring, and summer), and year (2010, 2011 new, and 2011_old) on the number of epicormic shoots (NUMB model)

Statistically significant values $(P<0.05)$ are given in bold. The factor year 2010 corresponds to epicormic branches produced in 2010, 2011 new corresponds to epicormic branches produced in 2011, and 2011_old corresponds to epicormic branches produced in 2010 and 2011 and collected at the end of 2011 growing season

$D F$ degrees of freedom

\begin{tabular}{lllll}
\hline Tested factors & Estimate value & Standard error & $D F$ & $P$ value \\
\hline (Intercept) & 2.59 & 0.33 & 188 & $<\mathbf{0 . 0 0 1}$ \\
Intensity 2/3 & 0.60 & 0.13 & 188 & $<\mathbf{0 . 0 0 1}$ \\
Season spring & -0.65 & 0.45 & 188 & 0.15 \\
Season summer & -2.14 & 0.38 & 188 & $<\mathbf{0 . 0 0 1}$ \\
Clone747210 & -0.33 & 0.36 & 6 & 0.40 \\
Clone915319 & 0.23 & 0.36 & 6 & 0.54 \\
CloneDN2 & -0.22 & 0.36 & 6 & 0.56 \\
year2011_new & -0.97 & 0.28 & 188 & $<\mathbf{0 . 0 0 1}$ \\
year2011_old & -0.40 & 0.28 & 188 & 0.16 \\
Seasonspring:year2011_new & 0.35 & 0.41 & 188 & 0.40 \\
Seasonsummer:year2011_new & 1.29 & 0.39 & 188 & $<\mathbf{0 . 0 0 1}$ \\
Seasonspring:year2011_old & 0.32 & 0.41 & 188 & 0.44 \\
Seasonsummer:year2011_old & 0.85 & 0.39 & 188 & $\mathbf{0 . 0 3}$ \\
Seasonspring:Clone747210 & 0.33 & 0.51 & 188 & 0.52 \\
Seasonsummer:Clone747210 & 0.77 & 0.44 & 188 & 0.09 \\
Seasonspring:Clone915319 & 0.30 & 0.51 & 188 & 0.55 \\
Seasonsummer:Clone915319 & 0.85 & 0.44 & 188 & 0.06 \\
Seasonspring:CloneDN2 & 1.07 & 0.52 & 188 & $\mathbf{0 . 0 4}$ \\
Seasonsummer:CloneDN2 & 1.58 & 0.44 & 188 & $<\mathbf{0 . 0 0 1}$ \\
\hline & & & & \\
\hline
\end{tabular}



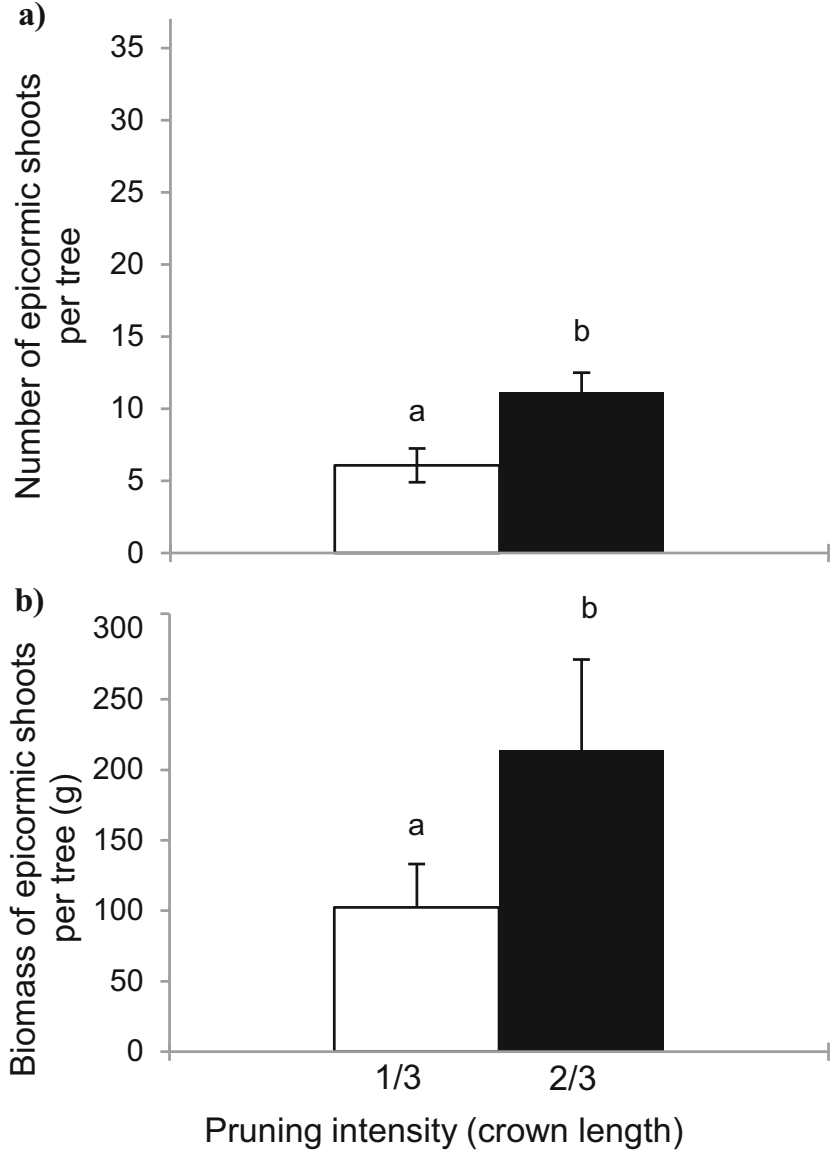

Fig. 1 Predictions for the mean number (a) and biomass (b) of epicormic shoots produced for each pruning intensity ( $1 / 3$ or $2 / 3$ crown length), all clones, seasons, and growing seasons combined. Error bars are standard errors of the mean. Bars labeled with the same letter within a graph are not significantly different (Tukey's test at $P<0.05$ )

\section{Results}

\subsection{Number and biomass of epicormic shoots}

All pruned trees but one produced epicormic shoots. The number of epicormic shoots produced after one growing season (2010) ranged from 0 to 97 . The model selected to explain the number of epicormic branches produced by trees included pruning intensity, year (1-year-old branches after the 2010 and 2011 [2011_new] growing seasons and 2-year-old branches [2011_old]), pruning season, clone, and the interactions season $\times$ year and season $\times$ clone (Tables 1 and 2). As expected, the number of epicormic shoots increased with pruning intensity (Fig. 1a). The four clones had similar responses to pruning intensity (Table 1; $P=0.54$ ), but clone DN2 produced more epicormic branches after summer pruning compared to clone 1079 (interaction clone $\times$ season; Fig. 2 a). Contrarily to our hypothesis, trees pruned in the fall and spring produced on average 3.5 times more epicormic shoots than trees
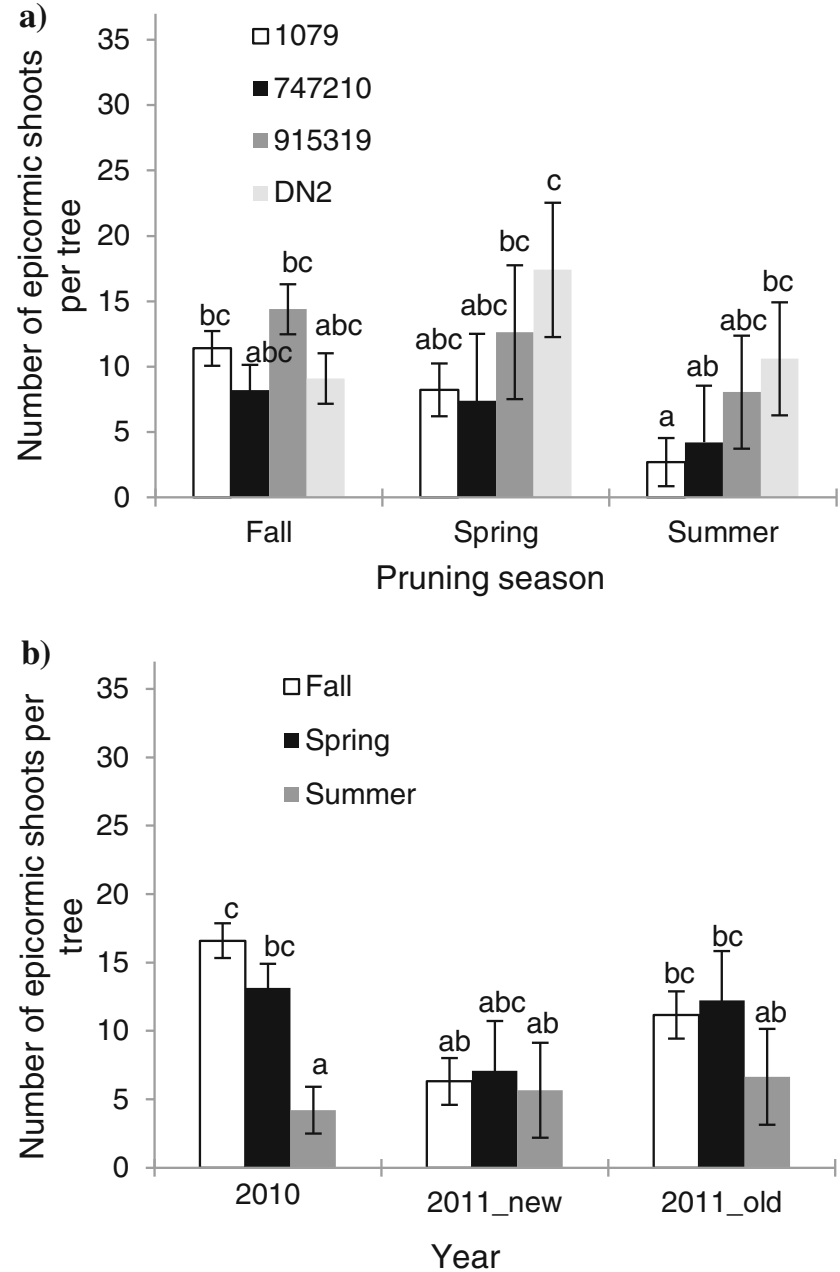

Fig. 2 Predictions of the mean number of epicormic shoots produced by trees, representing the interactions season $\times$ clone (a) and year $\times$ season (b), all pruning intensities combined. Year 2010 corresponds to epicormic branches produced in 2010, 2011 new corresponds to epicormic branches produced in 2011 and 2011 old corresponds to epicormic branches produced in 2010 and 2011 and collected at the end of 2011 growing season. Errors bars are standard errors of the mean. Bars labeled with the same letter are not significantly different (Tukey's test at $P<0.05$ )

pruned in the summer, during the 2010 growing season (Fig. 2b). When these first epicormic branches were removed, trees produced a little less new epicormic branches the following year ( 6.4 branches per tree on average; 2011 new). On the other hand, if epicormic branches produced during the first growing season (2010) were left on, trees had 10.0 epicormic branches on average after two growing seasons (2011_old; Fig. 2b). However, the number of epicormic shoots greatly varied during the second growing season, and the effect of pruning season was no longer significant in 2011 (Fig. 2b).

Biomass of epicormic branches was 2.1 times greater for the $2 / 3$ pruned trees compared to the $1 / 3$ pruned trees (Fig. 1b). Other than pruning intensity, mean biomass of epicormic branches was affected by the interaction year $x$ 
Table 3 Selected model testing the effect of pruning intensity (1/3, 2/3), season (fall, spring, summer), and year (2010, 2011_new, and 2011_old) on biomass of epicormic shoots (MASS model)

\begin{tabular}{|c|c|c|c|c|}
\hline Tested factors & Estimate value & Standard error & $D F$ & $P$ value \\
\hline (Intercept) & 5.38 & 0.33 & 126 & $<0.001$ \\
\hline year2011_new & -2.19 & 0.33 & 69 & $<0.001$ \\
\hline year2011_old & 0.75 & 0.36 & 126 & 0.04 \\
\hline Intensity $2 / 3$ & 0.73 & 0.18 & 126 & $<\mathbf{0 . 0 0 1}$ \\
\hline Seasonspring & -0.13 & 0.37 & 126 & 0.72 \\
\hline Seasonsummer & -1.50 & 0.35 & 126 & $<0.001$ \\
\hline year2011_new:Seasonspring & 0.39 & 0.48 & 69 & 0.41 \\
\hline year2011_old:Seasonspring & 0.34 & 0.52 & 126 & 0.52 \\
\hline year2011_new:Seasonsummer & 1.78 & 0.46 & 69 & $<0.001$ \\
\hline year2011_old:Seasonsummer & 0.08 & 0.50 & 126 & 0.87 \\
\hline
\end{tabular}

Significant $P$ values are given in bold. The factor year 2010 corresponds to epicormic branches produced in 2010, 2011_new corresponds to epicormic branches produced in 2011, and 2011_old corresponds to epicormic branches produced in 2010 and 2011 and collected at the end of 2011 growing season

$D F$ degrees of freedom

season (Tables 1 and 3), showing that the biomass of epicormic branches produced after one (2010) and two (2011_old) growing seasons was smaller for trees pruned in summer compared to trees pruned in fall and spring, while the biomass of epicormic shoots produced solely during the second growing season (2011_new) was smaller and independent of pruning season (Fig. 3).

\subsection{Growth responses}

Pruning 1/3 crown height slightly reduced height of trees after one and two growing seasons $(-2 \%)$, while it had no effect of stem dbh (Table 4 and Fig. 4). Pruning 2/3 of crown length

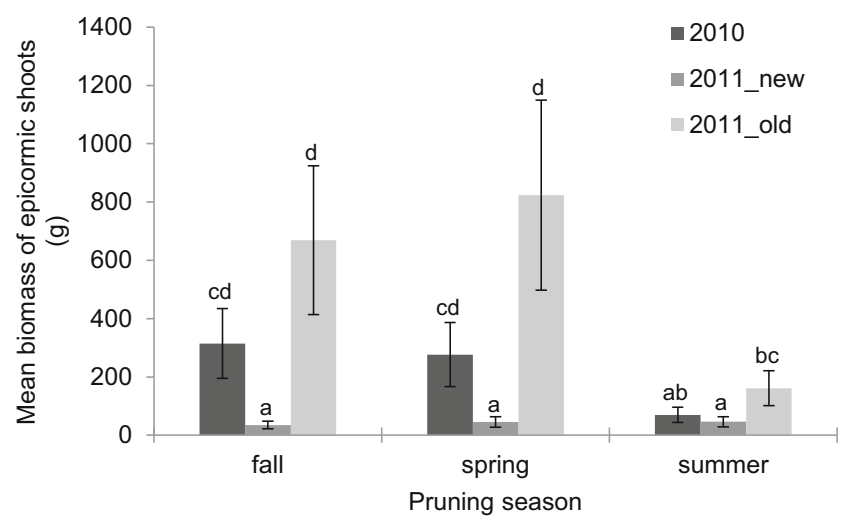

Fig. 3 Predictions for mean biomass of epicormic shoots per tree for each year and season combination, all clones and pruning intensities combined. Year 2010 corresponds to epicormic branches produced in 2010, 2011 new corresponds to epicormic branches produced in 2011, and 2011 old corresponds to epicormic branches produced in 2010 and 2011 and collected at the end of 2011 growing season. Errors bars are standard errors of the mean. Bars labeled with the same letter are not significantly different (Tukey's test at $P<0.05$ ) reduced height by 3 and $5 \%$ after one and two growing seasons, respectively, while basal diameter (dbh) of $2 / 3$ pruned trees was 4 and $8 \%$ smaller than unpruned trees, after one and two growing seasons, respectively (Fig. 4). Production of epicormic shoots did not affect tree breast height diameter and total height growth since pruned trees with or without epicormic shoots had similar dbhs and heights within a pruning intensity (Fig. 4).

\section{$3.3 \mathrm{TNC}$}

Model selection showed that only pruning intensity affected root TNC concentrations, while there was no effect of clone or pruning season (Tables 5 and 6). Root TNC concentrations were lower for all pruning treatments compared to unpruned trees, except for the $2 / 3$ pruned trees with epicormic shoots which had similar levels (Fig. 5). For a given pruning intensity, root TNC concentrations were similar between trees with or without epicormic shoots $(P>0.05)$.

\section{Discussion}

All four studied hybrid poplar clones responded to pruning by the production of epicormic shoots, which, however, did not affect dbh or height growth of pruned trees, since there was no difference in size between trees with or without epicormic shoots after one or two growing seasons.

Pruning intensity and season both affected the number of epicormic shoots produced after pruning; Trees pruned to $2 / 3$ crown length produced nearly twice as many epicormic 
Table 4 Models testing the effects of pruning treatment on tree height (HEIGHT10 and HEIGHT11) and dbh (DBH10 and DBH11) after the 2010 and 2011 growing seasons, respectively

\begin{tabular}{|c|c|c|c|c|c|}
\hline Model & Tested factors & Estimate value & Standard error & $D F$ & $P$ value \\
\hline \multirow[t]{6}{*}{ DBH10 } & (Intercept) & 23.24 & 1.61 & 962 & $<0.001$ \\
\hline & D2009 & 0.98 & 0.02 & 962 & $<0.001$ \\
\hline & Treatment 1 & 0.24 & 0.64 & 962 & 0.71 \\
\hline & Treatment 2 & -1.96 & 0.64 & 962 & 0.01 \\
\hline & Treatment E1 & 0.34 & 0.63 & 962 & 0.59 \\
\hline & Treatment E2 & -3.24 & 0.63 & 962 & $<0.001$ \\
\hline \multirow[t]{6}{*}{ HEIGHT10 } & (Intercept) & 165.62 & 13.59 & 962 & $<0.001$ \\
\hline & H2009 & 0.95 & 0.01 & 962 & $<0.001$ \\
\hline & Treatment 1 & -8.33 & 2.95 & 962 & 0.01 \\
\hline & Treatment 2 & -21.66 & 2.94 & 962 & $<0.001$ \\
\hline & Treatment E1 & -11.96 & 2.92 & 962 & $<0.001$ \\
\hline & Treatment E2 & -17.70 & 2.92 & 962 & $<0.001$ \\
\hline \multirow[t]{6}{*}{ DBH11 } & (Intercept) & 42.93 & 2.62 & 891 & 0.03 \\
\hline & D2009 & 1.08 & 0.02 & 891 & 0.52 \\
\hline & Treatment 1 & -23.46 & 0.83 & 891 & 0.09 \\
\hline & Treatment 2 & -25.83 & 0.82 & 891 & 0.55 \\
\hline & Treatment E1 & -0.04 & 0.89 & 891 & 0.06 \\
\hline & Treatment E2 & -4.40 & 0.89 & 891 & 0.04 \\
\hline \multirow[t]{6}{*}{ HEIGHT11 } & (Intercept) & 351.41 & 19.38 & 891 & $<0.001$ \\
\hline & H2009 & 0.92 & 0.02 & 891 & $<0.001$ \\
\hline & Treatment 1 & -179.15 & 3.99 & 891 & $<0.001$ \\
\hline & Treatment 2 & -192.22 & 3.97 & 891 & $<0.001$ \\
\hline & Treatment E1 & -14.68 & 4.30 & 891 & $<0.001$ \\
\hline & Treatment E2 & -36.08 & 4.27 & 891 & $<0.001$ \\
\hline
\end{tabular}

Statistically significant values $(P<0.05)$ are given in bold. Treatment corresponds to the combination between pruning intensity and epicormic branches treatment $(1=1 / 3$ pruned tree without epicormic shoots, $2=2 / 3$ pruned tree without epicormic shoots, $\mathrm{E} 1=1 / 3$ pruned tree with epicormic shoots, $\mathrm{E} 2=2 / 3$ pruned tree with epicormic shoots)

$D F$ degrees of freedom

branches with over twice the biomass of $1 / 3$ pruned trees (Fig. 1), which could be interpreted as a means for trees to restore the balance between leaf area and non-photosynthetic organs (Nicolini et al. 2001). Heavy pruning has been shown to be a significant promoter of epicormic sprouting (Gordon et al. 2006; Waring and O'Hara 2005). The absence of interactions between pruning intensity and clone or pruning season is indicative that one can expect similar responses to pruning intensity regardless of the clone or of when pruning is done.

The removal of foliage with pruning caused decreases in root TNC concentrations compared to unpruned trees (Fig. 5). This drop in TNC was either due to the production of new foliage and/or the reduction of photosynthate production by the remaining leaves of pruned trees (Lovett and Tobiessen 1993). Although 2/3 pruning approximately doubled the amount of foliage removed and the amount of epicormic branches produced, root TNC reserves were similar between the two pruning intensities. This suggests that root TNC reserves were not proportionally solicited to re-establish photosynthetic capacity of trees or to supply carbohydrates for respiration demands of trees. The fact that root TNC concentrations were similar for trees with or without epicormic branches within a pruning treatment indicate that the photosynthates produced by epicormic branches were not entirely exported to the roots and were probably mostly used to support the growth and maintenance of their large biomasses. Our results also show that more than one growing season post-pruning will be required for trees to reconstitute root TNC concentrations to similar levels of unpruned trees.

Trees pruned in summer produced the least epicormic shoots after one growing season (Fig. 2b), consistent with previous studies such as Wignall et al. (1987) in oak (Quercus robur L.) or Bachelard (1969) in Eucalyptus polyanthemos. Season of pruning was also found to be the most important factor affecting shoot initiation and growth in Prunus persica (Gordon et al. 2006). The fewer 
Fig. 4 Predictions for height and $\mathrm{dbh}$, one (a, b) and two (c, d) growing seasons after pruning on trees with $(1 / 3$ epi, $2 / 3$ epi) or without $(0=$ unpruned, $1 / 3,2 / 3)$ epicormic shoots, all clones combined. Errors bars are standard errors of the mean. Bars labeled with the same letter within a graph are not significantly different (Tukey's test at $P<0.05$ )
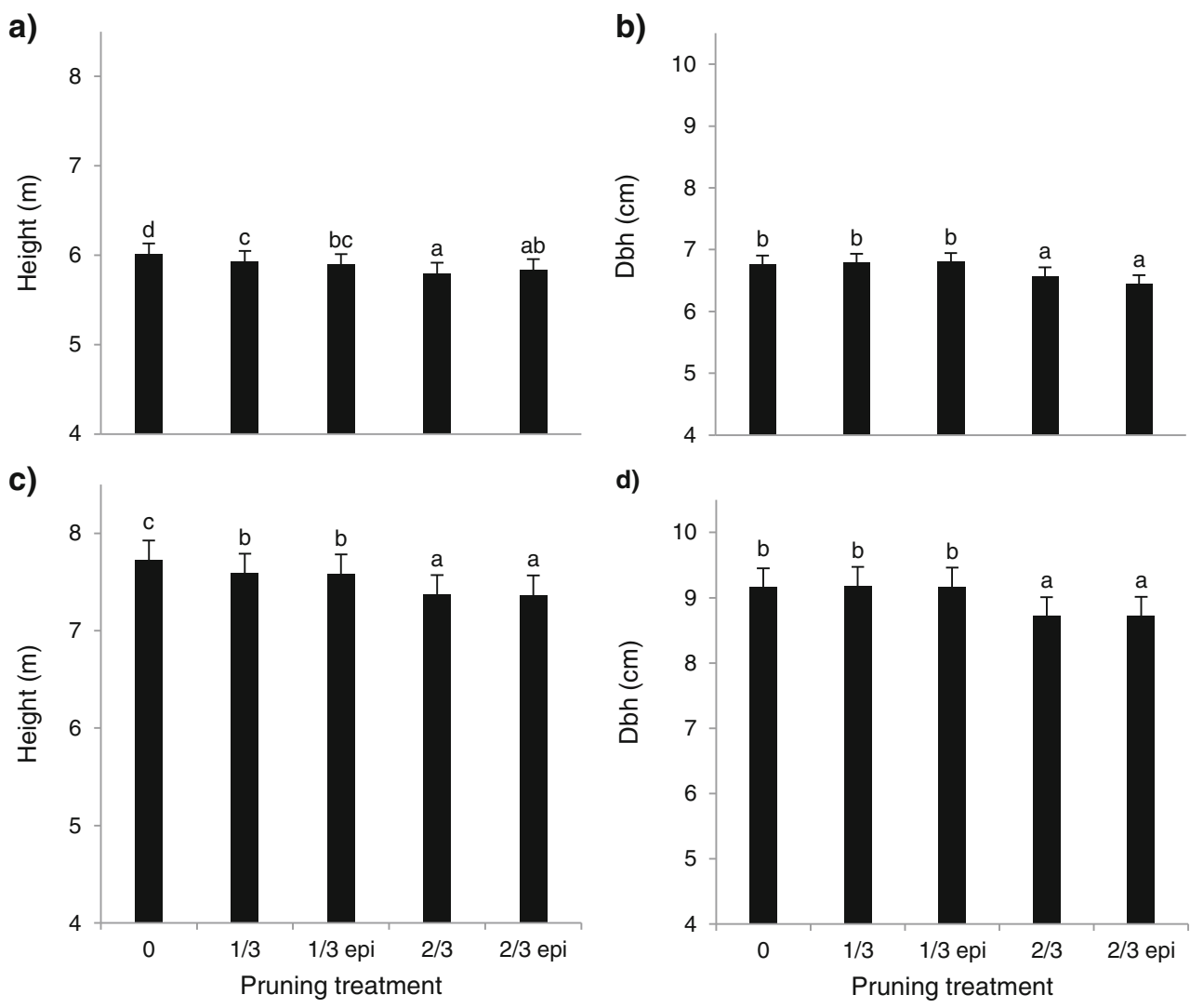

d)

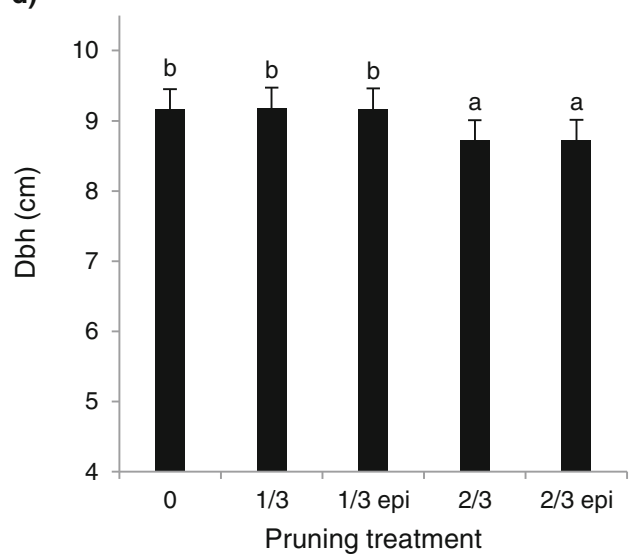

epicormic shoots produced by summer-pruned trees could be explained by the fact that development of epicormic shoots depends on bud break, which occurs at the beginning of the leafy period (Harmer 1988), on light availability in early spring and on light availability throughout

Table 5 Global model testing the effect of pruning (unpruned, 1/3 and $2 / 3$ pruning of crown length), season (fall, spring, and summer), and clone $(1079,747210,915319$, and DN2) on root total non-structural carbohydrate concentrations (TNC) of trees with or without epicormic shoots

\begin{tabular}{lllll}
\hline Tested factors & numDF & $\operatorname{denDF}$ & $F$ value & $P$ value \\
\hline (Intercept) & 1 & 112 & 185.51 & $<\mathbf{0 . 0 0 1}$ \\
Clone & 3 & 6 & 1.14 & 0.40 \\
Treatment & 4 & 112 & 4.34 & $<\mathbf{0 . 0 0 1}$ \\
Season & 2 & 112 & 1.86 & 0.16 \\
Clone:Treatment & 12 & 112 & 1.03 & 0.43 \\
Clone:Season & 6 & 112 & 1.41 & 0.22 \\
Treatment:Season & 8 & 112 & 0.58 & 0.79 \\
Clone:Treatment:Season & 24 & 112 & 1.07 & 0.39 \\
\hline
\end{tabular}

Significant $P$ values are given in bold. Treatment corresponds to the combination between pruning intensity and epicormic branch treatment (unpruned, 1/3 pruned with or without epicormic shoots and 2/3 pruned with or without epicormic shoots

NumDF numerator of degrees of freedom, $\operatorname{den} D F$ denominator of degrees of freedom the growing season (Colin et al. 2008). Trees pruned in fall or spring had more available light at the time of bud break and also had more time to develop epicormic buds over the growing season. Moreover, paradormancy of epicormic buds, dormancy moderated by plant structures external of the buds (Lang 1987), could be largely controlled by downward auxin transport from young expanding leaves (Aloni et al. 2003), which were absent when trees were pruned in the fall and spring (before leaf flush). It is also thought that epicormic buds could be

Table 6 Selected model testing the effect of pruning treatment on root total non-structural carbohydrate concentrations (TNC)

\begin{tabular}{lllll}
\hline Tested factors & Estimate value & Standard error & $D F$ & $P$ value \\
\hline (Intercept) & 15.63 & 1.29 & 164 & $<\mathbf{0 . 0 0 1}$ \\
Treatment 1 & -4.63 & 1.45 & 164 & $\mathbf{0 . 0 0 2}$ \\
Treatment 2 & -5.56 & 1.45 & 164 & $<\mathbf{0 . 0 0 1}$ \\
Treatment E1 & -3.94 & 1.45 & 164 & $\mathbf{0 . 0 0 7}$ \\
Treatment E2 & -3.72 & 1.45 & 164 & $\mathbf{0 . 0 1 1}$
\end{tabular}

Significant $P$ values are given in bold. Treatment corresponds to the combination between pruning intensity and epicormic branches treatment $(1=1 / 3$ pruned tree without epicormic shoots, $2=2 / 3$ pruned tree without epicormic shoots, $\mathrm{E} 1=1 / 3$ pruned tree with epicormic shoots, $\mathrm{E} 2=2 / 3$ pruned tree with epicormic shoots).

$D F$ degrees of freedom 


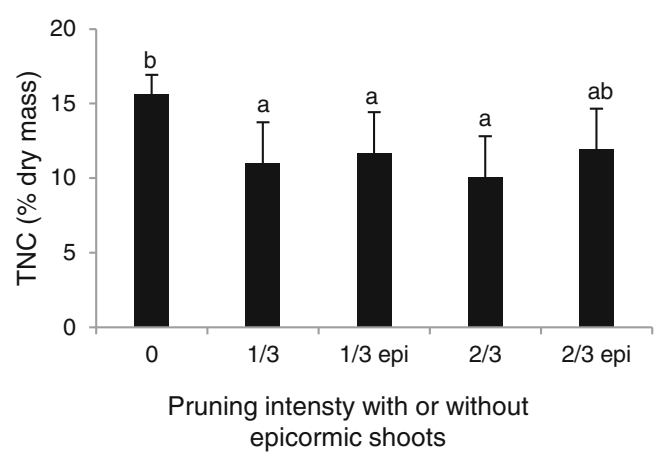

Fig. 5 Predictions for mean total non-structural root carbohydrates for unpruned trees $(0), 1 / 3$ pruned trees without epicormic shoots $(1 / 3), 1 / 3$ pruned trees with epicormic shoots $(1 / 3$ epi $), 2 / 3$ pruned trees without epicormic shoots $(2 / 3)$, and $2 / 3$ pruned trees with epicormic shoots $(2 / 3$ epi), all clones and pruning seasons combined. Errors bars are standard errors of the mean. Bars labeled with the same letter are not significantly different (Tukey's test at $P<0.05$ )

entering dormancy early in the growing season (Wignall et al. 1987), in this case due to the physiology of the bud itself, i.e., endodormancy (Lang 1987). When the epicormic branches produced in 2010 were left to grow on trees until the end of 2011 , i.e., for two growing seasons (2011_old), the effect of pruning season was no longer significant and trees had similar numbers of epicormic shoots (Fig. 2b). This suggests that summerpruned trees produced new epicormic shoots in 2011 or that some epicormics from fall- and spring-pruned trees died during the second growing season (Takiya et al. 2010; Waring and O'Hara 2005). However, biomass of these epicormic branches shows that even though numbers of 2-year-old branches (2011_old) were similar for all pruning seasons (Fig. 2b), their biomass was much smaller in summer-pruned trees (Fig. 3). This underlines the importance of removing epicormic branches produced on fall- or spring-pruned trees, to avoid very large knots on boles. Epicormic branches produced in 2011 (2011_new) were also in comparable numbers than 2year-old branches (Fig. 2b) but had much less biomass (Fig. 3), indicating that trees produced much smaller epicormic branches during the second growing season after pruning.

In our study, growth rate did not affect the number of epicormic shoots produced after pruning, since clone DN2 $(P$. deltoides $\times P$. nigra), which had the highest growth rates, produced similar numbers of epicormic shoots than clone $747210(P$. balsamifera $\times$ P. trichocarpa), which had the lowest growth rate. Others had found that smallsized or slower growing trees produced more epicormic shoots than large dominant trees (Nicolini et al. 2003; O'Hara and Valappil 2000). In this case, the effect of tree size and vigor was probably related to the comparative strength of carbohydrate sinks between sequential and epicormic buds. Large sequential buds of expanding shoots in the upper canopy are strong sinks compared small epicormic buds located lower on the stem, while this difference in sink strength is much reduced in suppressed trees, which could lead to greater epicormic shoot development (Meier et al. 2012). In our study, however, trees were of the same age and of relatively similar sizes and social position in the canopy due to their clonal nature, which could explain why growth rates were unrelated to epicormic shoot production.

\subsection{Silvicultural implications}

Based on this experiment, we recommend pruning $1 / 3$ crown length in summer to reduce the number and biomass of epicormic shoots produced from the stress of pruning. However, if pruning needs to be done during the dormant season, a second pruning to remove epicormic shoots should be planned after the next growing season to prevent them reaching very large sizes (biomasses). Epicormic shoots did not affect tree diameter growth 1 or 2 years after treatment. Hence, we conclude that epicormic branches can be removed by plantation managers without compromising tree growth, if a greater quality bole is desired.

\section{Conclusion}

In summary, pruning hybrid poplars at any intensity or season resulted in the production of epicormic shoots. Pruning intensity had a strong effect on the number and biomass of epicormic shoots produced after one and two growing seasons, approximately doubling between pruning $1 / 3$ and $2 / 3$ crown length. Pruning trees in summer produced the least number of epicormic shoots after one and two growing seasons. Hormonal control of paradormancy of epicormic buds from young expanding canopy shoots and from self-regulated endodormancy of buds during the summer season most probably explains this result. An additional pruning during the first growing season (removal of the epicormic branches) significantly reduced the size of new epicormic shoots produced the next year for all pruning treatments. Epicormic shoot production did not restore root carbohydrate reserves one growing season following pruning nor did it affect tree growth 1 or 2 years after treatment. Hence, we conclude that epicormic branches can be removed by plantation managers without compromising tree growth, if a greater quality bole is desired, because they reached very large size during the second growing season.

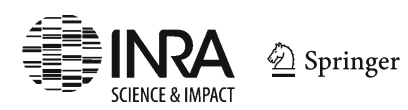


Acknowledgments We thank the Sustainable Center for Forest Research, Quebec Ministry of Natural Resources, Réseau Ligniculture Québec, University of Guelph - New Liskeard Agricultural Research Station, Northern College, Line Blackburn, and other technicians for field and lab work.

Funding This work was supported by the Canadian Ecology Centre Forestry Research Partnership [FRP Project no. 130-701], Tembec, the government of Ontario, Natural Resources Canada - Canadian Forest Service, and by Alberta-Pacific Forest Industries, Norbord, and the Natural Sciences and Engineering Research Council of Canada through a collaborative research and development grant [CRDPJ $381553-09$ to A.D.].

\section{References}

Aloni R, Schwalm K, Langhans M, Ullrich C (2003) Gradual shifts in sites of free-auxin production during leaf-primordium development and their role in vascular differentiation and leaf morphogenesis in Arabidopsis. Planta 216:841-853

Auchmoody LR (1972) Epicormic branching: seasonal change, influence of fertilization, and frequency of occurrence in uncut stands. USDA Forest Service Res. Note NE-228

Bachelard EP (1969) Studies on the formation of epicormic shoots on eucalypt stem segments. Aust J Biol Sci 22:1291-1296

Canada Soil Survey Committee (1987) The Canadian System of Soil Classification. Canadian Department of Agriculture, Supply and Services Canada, Ottawa, 1646

Chow PS, Landhäusser SM (2004) A method for routine measurements of total sugar and starch content in woody plant tissues. Tree Physiol 24:1129-1136

Colin F, Robert N, Druelle JL, Fontaine F (2008) Initial spacing has little influence on transient epicormic shoots in a 20-year-old sessile oak plantation. Ann For Sci 65:508-508

Deal RL, Barbour RJ, Mcclellan MH, Parry DL (2003) Development of epicormic sprouts in Sitka spruce following thinning and pruning in south-east Alaska. Forestry 76:401-412

DeBell DS, Singleton R, Harrington CA, Gartner BL (2002) Wood density and fiber length in young Populus stems: relation to clone, age, growth rate, and pruning. Wood Fiber Sci 34:529-539

Environment Canada (2014) National Climate Archives. http://climate. weather.gc.ca/ (accessed October 2014)

Fink S (1983) The occurrence of adventitious and preventitious buds within the bark of some temperate and tropical trees. Am J Bot 70:532-542

Fontaine F, Kiefer E, Clément C, Burrus M, Druelle JL (1999) Ontogeny of the proventitious epicormic buds in Quercus petraea. II. From 6 to 40 years of the tree's life. Trees 14:83-90

Gordon D, Rosati A, Damiano C, Dejong TM (2006) Seasonal effects of light exposure, temperature, trunk growth and plant carbohydrate status on the initiation and growth of epicormic shoots in Prunus persica. J Hortic Sci Biotechnol 81:421-428

Harmer R (1988) Production and use of epicormic shoots for the vegetative propagation of mature oak. Forestry 61:305-316

Hothorn T, Bretz F, Westfall P (2008) Simultaneous inference in general parametric models. Biom J 50:346-363

Hubert M, Courraud R (1994) Élagage et taille de formation des arbres forestiers, 2nd edn. IDF, Paris, $303 \mathrm{p}$

Isebrands JG, Rosemeier D, Wyatt G, Zamora D (2007) Best management practices poplar manual for agroforestry applications in Minnesota. Environmental Forestry Consultants, LLC
Kozlowski TT (1992) Carbohydrate sources and sinks in woody plants. Bot Rev 58:107-222

Kozlowski TT, Pallardy SG (1997) Physiology of woody plants, 2nd edn. Academic, San Diego, 411 p

Lang GA (1987) Dormancy: a new universal terminology. Hortscience 22:817-820

Lovett GM, Tobiessen P (1993) Carbon and nitrogen assimilation in red oaks (Quercus rubra L.) subject to defoliation and nitrogen stress. Tree Physiol 12:259-269

Maurin V, DesRochers A (2013) Hybrid poplar physiological and growth responses to pruning season and intensity. For Ecol Manag 304: 399-406

Meier AR, Saunders MR, Michler CH (2012) Epicormic buds in trees: a review of bud establishment, development and dormancy release. Tree Physiol 32:565-584

Nicolini E, Chanson B, Bonne F (2001) Stem growth and epicormic branch formation in understorey beech trees (Fagus sylvatica L.). Ann Bot-Lond 87:737-750

Nicolini E, Caraglio Y, Pelissier R, Leroy C, Roggy JC (2003) Epicormic branches: a growth indicator for the tropical forest tree, Dicorynia guianensis Amshoff (Caesalpiniaceae). Ann BotLond 92:97-105

O'Hara KL, Valappil NI (2000) Epicormic sprouting of pruned western larch. Can J Forest Res 30:324-328

Pinheiro J, Bates D, DebRoy S, Sarkar D, The R Development Core Team (2012) Nlme: linear and nonlinear mixed effects models. R package version 3.1-104

R Development Core Team (2012) R: a language and environment for statistical computing. R Foundation for Statistical Computing, Version 2.15.1. Vienna, Austria

Remphrey WR, Davidson CG (1992) Spatiotemporal distribution of epicormic shoots and their architecture in branches of Fraxinus pennsylvanica. Can J Forest Res 22:336-340

Rowe JS (1972) Forest regions of Canada. Canadian Forestry Service, Ottawa, $172 \mathrm{p}$

Shock C, Feibert E, Eaton J (2003) Effect of pruning severity on the annual growth of hybrid poplar. Maiheur Exp Sta, Ann Rep 2003, Oregon State University, Spec Rep 1055

Smith JHG, Blom G (1966) Decade of intensive cultivation of poplars in British Columbia shows need for long-term research to reduce risks. For Chron 42:359-376

Smith DM, Larson BC, Kelty MJ, Ashton PMS (1997) The practice of silviculture: applied forest ecology, 9th edn. Wiley, New York

Stone EL, Stone MH (1943) "Dormant" versus "adventitious" buds. Science 98:62

Tabbush P, Beaton A (1998) Hybrid poplars: present status and potential in Britain. Forestry 71:355-364

Takiya M, Koyama H, Umeki K, Yasaka M, Ohno Y, Watanabe I, Terazawa K (2010) The effects of early and intense pruning on light penetration, tree growth, and epicormic shoot dynamics in a young hybrid larch stand. J For Res-Jpn 15:149-160

van Oosten C (2006) Hybrid poplar crop manual for the Prairie Provinces. Saskatchewan Forest Centre, Prince Albert

Waring KM, O'Hara KL (2005) Ten-year growth and epicormic sprouting response of western larch to pruning in western Montana. Wes J Appl For 20:228-232

Wignall TA, Browning G (1988) The effects of stand thinning and artificial shading on epicormic bud emergence in pedunculate oak (Quercus robur L.). Forestry 61:45-59

Wignall TA, Browning G, Mackenzie KAD (1987) The physiology of epicormic bud emergence in pedunculate oak (Quercus robur L.). Responses to partial notch girdling in thinned and unthinned stands. Forestry 60:45-56 